\title{
The Role of Streptomycetes in Decomposition of Chitin in Acidic Soils
}

\author{
By S. T. WILLIAMS* AND C. S. ROBINSON \\ Department of Botany, Liverpool University, Liverpool L69 3BX, U.K.
}

(Received 22 January 1981)

The influence of $\mathrm{pH}$ on chitin hydrolysis by streptomycetes from a range of acidic and neutral soils was studied in vitro in an acid soil. On the basis of activity ranges and optima for chitin hydrolysis, acidophilic, acidoduric and neutrophilic categories of streptomycetes were distinguished; these categories were broadly related to the $\mathrm{pH}$ requirements for growth. $\mathrm{Re}$ sponses of streptomycetes to chitin amendment of acidic organic and mineral horizons of a pine forest soil were studied. Acidophiles were involved in the decomposition process and the resulting ammonification led subsequently to activity of neutrophiles. This succession was particularly marked in the poorly buffered mineral horizon. Similar, but smaller, responses occurred when the horizons were amended with mycelium from basidiomycete sporocarps. The role of streptomycetes in decomposition of fungal chitin in acidic litters and soils is discussed.

\section{INTRODUCTION}

Previous studies of the $\mathrm{pH}$ requirements of soil streptomycetes have distinguished between neutrophiles which grow from $\mathrm{pH} 5.0$ to 9.0 with optima close to $\mathrm{pH} 7.0$, and acidophiles which grow from $\mathrm{pH} 3.5$ to 6.5 with optima from $\mathrm{pH} 4.5$ to 5.5 (Jensen, 1928; Williams $e t$ al., 1971; Flowers \& Williams, 1977). Acidophiles appear to be restricted to acidic soils and litters; neutrophiles are most numerous in soils close to neutrality but also occur in low numbers in acidic soils (Williams \& Mayfield, 1971). Acidophiles probably play an important part in decomposition processes in acidic soil and litter. They have a diversity of hydrolytic abilities (Khan \& Williams, 1975) and many produce extracellular diastases with optimum activity between pH 4.0 and 4.5 (Williams \& Flowers, 1978).

Ability to degrade chitin is one of the most characteristic features of soil streptomycetes. Chitin media are often used to isolate and enumerate streptomycetes (Lingappa \& Lockwood, 1962; Hsu \& Lockwood, 1975). Extracellular chitinases have been isolated from several laboratory cultures (Jeuniaux, 1955; Berger \& Reynolds, 1958; Skujins et al., 1970; Tiunova et al., $1976 a, b)$. Amendment of soil with chitin leads to a large increase in numbers of streptomycetes, which may result in the suppression of root pathogenic fungi (Mitchell \& Alexander, 1962; Sneh et al., 1971). A similar stimulation of streptomycetes occurs when fungal cell-wall components are added to soil (Mitchell, 1963) and it is likely that fungal hyphae provide a major source of chitin for streptomycetes in soil. Another potential source of chitin is the exoskeletons of soil arthropods (Okafor, 1966).

Therefore we decided to study the roles of acidophilic and neutrophilic streptomycetes in the decomposition of pure chitin and fungus mycelium in acidic soil and litter. An initial survey was made of the effects of $\mathrm{pH}$ on chitin hydrolysis by streptomycetes in vitro. The responses of the streptomycete populations in a litter and soil horizon of an acidic pine forest soil (Freshfield, Merseyside, U.K.) to amendment with chitin and fungus mycelium were then studied. General aspects of chitin decomposition in this soil were previously examined by Gray \& Baxby (1968) and the ecology of the streptomycete population has been intensively studied. 


\section{METHODS}

Selection of chitin-hydrolysing soil isolates. A total of 24 streptomycetes previously isolated from a range of acidic and neutral soils were tested for their ability to hydrolyse chitin. Acidophilic and acidoduric isolates were inoculated on to a medium containing $(\%, w / v)$ : colloidal chitin (prepared by the method of Hsu \& Lockwood, 1975), 0.3; $\mathrm{MgSO}_{4} .7 \mathrm{H}_{2} \mathrm{O}, 0.05 ; \mathrm{FeSO}_{4} .7 \mathrm{H}_{2} \mathrm{O}, 0.001 ; \mathrm{ZnSO}_{4} .7 \mathrm{H}_{2} \mathrm{O}, 0.0001 ; \mathrm{MnCl}_{2} .4 \mathrm{H}_{2} \mathrm{O}, 0.0001 ; \mathrm{KH}_{2} \mathrm{PO}_{4}$, 0.5 ; Bacto agar (Difco), 2.0; the final $\mathrm{pH}$ was 5.5. Neutrophiles were grown on the same medium but with $0.1 \%(\mathrm{w} / \mathrm{v}) \mathrm{K}_{2} \mathrm{HPO}_{4}$ substituted for $\mathrm{KH}_{2} \mathrm{PO}_{4}$; the final $\mathrm{pH}$ was 7.0. Spore suspensions of the isolates (stored in $10 \%, \mathrm{v} / \mathrm{v}$, glycerol at $-20^{\circ} \mathrm{C}$; Wellington \& Williams, 1978) were used to point-inoculate the medium, each plate receiving five replicate inoculations of $0.01 \mathrm{ml}$ of suspension. Plates were incubated at $25^{\circ} \mathrm{C}$ for $14 \mathrm{~d}$ and the colony areas and diameters of hydrolysis zones were measured.

Effect of $\mathrm{pH}$ on chitin hydrolysis. The 10 strains which produced the largest hydrolysis zones were used. Origins of these strains are given in Table 1 . The reaction of the chitin/mineral salts medium was adjusted to cover the

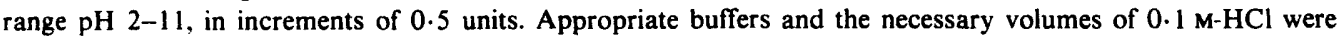

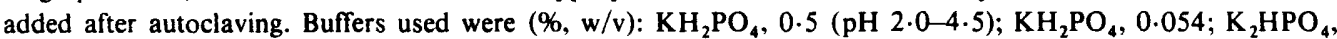
$0.035: \mathrm{Na}_{2} \mathrm{HPO}_{4}, 0.028(\mathrm{pH} 5.0-6.0) ; \mathrm{K}_{2} \mathrm{HPO}_{4}, 0.07 ; \mathrm{Na}_{2} \mathrm{HPO}_{4}, 0.056\left(\mathrm{pH} \mathrm{6.5-8.0)} ; \mathrm{Na}_{2} \mathrm{~B}_{4} \mathrm{O}_{7} . \mathrm{H}_{2} \mathrm{O}, 0.095 ;\right.$ $\mathrm{NaOH}, 0 \cdot 018$ (pH 8.5-11.0).

Plates were point-inoculated, with five replicate inoculations for each isolate at each $\mathrm{pH}$. After incubation at $25^{\circ} \mathrm{C}$ for $21 \mathrm{~d}$, the areas of hydrolysis zones and colonies were calculated. The $\mathrm{pH}$ of all media was also checked and only slight changes $( \pm 0.1$ unit) were detected.

The $\mathrm{pH}$ at which each isolate produced its largest hydrolysis zone was noted. In order to assess the effect of $\mathrm{pH}$ on chitin hydrolysis independently of its effects on streptomycete growth, cylinders of medium (6 mm diam.) free of streptomycete growth were aseptically removed from these hydrolysis zones. These were placed on to the surface of fresh chitin/mineral salts medium previously adjusted to $\mathrm{pH} 2-11$ in 1 unit increments. Five replicate cylinders were transferred to the medium at each $\mathrm{pH}$. Plates were incubated at $25^{\circ} \mathrm{C}$ for $14 \mathrm{~d}$, after which the diameter of hydrolysis zones around the discs was measured. The cylinders rapidly equilibrated to the $\mathrm{pH}$ of the plates on which they were placed.

Effects of chitin and fungal mycelium amendments on streptomycetes in an acidic soil

(i) Selection and properties of soil. The soil selected was a developing podzol under Pinus nigra at Freshfield, Merseyside. U.K. Previous studies of the $\mathrm{pH}$ requirements of streptomycetes in this soil showed that mixed populations of acidophiles and neutrophiles occurred in the adjacent $\mathrm{F}_{2}-\mathrm{H}$ litter and $\mathrm{A}_{1}$ horizons (Williams et al., 1971). As they also provided a contrast between a totally organic and a primarily mineral horizon, they were selected for this study.

The humic acid content of each horizon was estimated, as humus is the most potent buffering agent in soil (Russell, 1973). A $2 \mathrm{~g}$ sample of air-dried, sieved soil was added to $20 \mathrm{ml} 0.5 \mathrm{M}-\mathrm{NaOH}$ in a $100 \mathrm{ml}$ conical flask. The suspension was shaken orbitally $\left(190 \mathrm{rev} . \min ^{-1}\right)$ for $24 \mathrm{~h}$ at room temperature. The supernatant was collected after centrifugation at $3000 \mathrm{~g}$ for $10 \mathrm{~min}$, the whole procedure being repeated until the supernatant was clear. Combined extracts were acidified with $1.0 \mathrm{M}-\mathrm{HCl}$, resulting in precipitation of the humic acid fraction, which was then sedimented by centrifugation. The sediment was washed three times with distilled water, dried and weighed. Five replicate determinations were made for each horizon.

The buffering capacity of each horizon was estimated. Samples of fresh soil $(10 \mathrm{~g})$ were placed into vials, and from 1 to $19 \mathrm{ml} 0.04 \mathrm{M}-\mathrm{NaOH}$ (in $1 \mathrm{ml}$ increments) was added to the vials, the volume being made up to $20 \mathrm{ml}$ with distilled water. Distilled water alone was added to control vials. The same procedure was applied to acid-washed sand and 1.0 M-citrate buffer which served as examples of poorly and well buffered systems, respectively. After $30 \mathrm{~min}$ equilibration, the $\mathrm{pH}$ of all suspensions was determined with a glass electrode.

An indication of the natural occurrence of chitin in both horizons was obtained by determination of their hexosamine content (Stevenson, 1965).

(ii) Effects of chitin and fungal mycelium amendments. Samples $(8 \mathrm{~g})$ of freshly collected $\mathrm{F}_{2}-\mathrm{H}$ litter and $\mathrm{A}_{1}$ soil were placed in sterile McCartney vials. Sterile flaked chitin (BDH) was added to half the vials $(2.5 \%$, w/w) and mixed well; the unamended vials served as controls. Tops were lightly screwed and the vials were incubated at $25^{\circ} \mathrm{C}$ for $40 \mathrm{~d}$, their moisture content being maintained by regular additions of sterile deionized water.

At the beginning of the experiment and at $10 \mathrm{~d}$ intervals, the $\mathrm{pH}$ and ammonium- $\mathrm{N}$ concentration were determined. Three replicate vials were used for each determination. The $\mathrm{pH}$ was determined by placing a glass electrode into a paste of soil plus deionized water $(1: 1$, by vol.) which had been allowed to equilibrate for $30 \mathrm{~min}$. The ammonium- $\mathrm{N}$ concentration in $2 \mathrm{M}-\mathrm{KCl}$ extracts of soil or litter was measured using the indophenol blue method of Kempers (1974), a modification of that of Weatherburn (1967).

Numbers of streptomycetes were estimated at the beginning and end of the experimental period by the dilution plate procedure, using starch/casein medium (Küster \& Williams, 1964) at $\mathrm{pH} 4.5$ and 7.0 , and chitin/mineral salts medium adjusted to the $\mathrm{pH}$ of the material in the vials at the time of sampling. All media contained the antifungal antibiotics nystatin (Squibb, Twickenham, Middlesex) and cycloheximide (Koch-Light, Colnbrook, 
Table 1. Origins of streptomycete isolates used to study effect of $\mathrm{pH}$ on chitin hydrolysis

$\begin{array}{llc}\begin{array}{c}\text { Streptomyces } \\ \text { strain }\end{array} & \text { Soil type } & \text { Soil pH } \\ \text { SW9 } & \text { Podzol } & 3.5 \\ \text { SW26 } & \text { Juncus litter } & 4.0 \\ \text { MR2 } & \text { Podzol } & 3.8 \\ \text { HF3 } & \text { Podzol } & 3.9 \\ \text { SW72 } & \text { Coal spoil } & 4.5 \\ \text { H } & \text { Podzol } & 3.5 \\ \text { C1 } & \text { Sand dune } & 7.8 \\ \text { C5 } & \text { Sand dune } & 7.8 \\ \text { F70 } & \text { Sand } & 7.5 \\ \text { M1 } & \text { Brown earth } & 5.5\end{array}$

Bucks.) each at a concentration of $50 \mu \mathrm{g} \mathrm{m} \mathrm{m}^{-1}$. After incubation at $25^{\circ} \mathrm{C}$ for $14 \mathrm{~d}$, the colonies on all media at appropriate dilutions were counted. The number of colonies producing hydrolysis zones on the chitin medium was also noted.

The proportions of acidophilic, acidoduric and neutrophilic strains were estimated. Twenty colonies were randomly picked off from plates of each medium/treatment combination. Each colony was divided and inoculated into a tube of broth at $\mathrm{pH} 4.5$ and at $\mathrm{pH} \mathrm{7.0.} \mathrm{The} \mathrm{medium} \mathrm{contained} \mathrm{( \% ,} \mathrm{w/v):} \mathrm{glucose,} \mathrm{1.0;} \mathrm{L-asparagine,} \mathrm{0.05;}$ $\mathrm{MgSO}_{4} .7 \mathrm{H}_{2} \mathrm{O}, 0.05 ; \mathrm{FeSO}_{4} .7 \mathrm{H}_{2} \mathrm{O}, 0.001 ; \mathrm{ZnSO}_{4} .7 \mathrm{H}_{2} \mathrm{O}, 0.0001 ; \mathrm{MnCl}_{2} .4 \mathrm{H}_{2} \mathrm{O}, 0.0001$. The reaction was adjusted after sterilization by addition of either $\mathrm{KH}_{2} \mathrm{PO}_{4}\left(\mathrm{pH} \mathrm{4.5)}\right.$ or $\mathrm{K}_{2} \mathrm{HPO}_{4}(\mathrm{pH} 7.0)$ to a final concentration of $0.5 \%(w / w)$. Presence or absence of growth was noted after $7 \mathrm{~d}$ at $25{ }^{\circ} \mathrm{C}$. Acidophiles were recognized by growth at $\mathrm{pH} 4.5$ only, acidodurics by growth at $\mathrm{pH} 4.5$ and 7.0 , and neutrophiles by growth at $\mathrm{pH} 7.0$ only.

The same procedures were used in a more intensive study of streptomycetes in chitin-amended $A_{1}$ soil. The experimental period was reduced to $20 \mathrm{~d}$ and streptomycete populations were studied at $5 \mathrm{~d}$ intervals.

Changes in $\mathrm{pH}$, ammonium- $\mathrm{N}$, and streptomycete populations in both horizons amended with fungus mycelium were also studied. Fungus material was obtained from the fruit bodies of Lactarius rufus, which were numerous in the pine forest. Fresh fruit bodies were cut into small pieces, air-dried and ground to pass through a $500 \mu \mathrm{m}$ mesh sieve. The resulting powder was added to soil or litter $(2.5 \%, w / w)$ and determinations were carried out as with the chitin amendments.

\section{RESULTS}

\section{Effect of $\mathrm{pH}$ on chitin hydrolysis in vitro}

Measurement of the colony areas of streptomycetes on chitin medium at different $\mathrm{pH}$ values indicated that three categories could be distinguished. Acidophiles grew between $\mathrm{pH} 4.0$ and 6.0, with an optimum around $\mathrm{pH} 4.5$; acidoduric isolates grew from $\mathrm{pH} 4.5$ to 8.5 , with an optimum near $\mathrm{pH} 6.5$; neutrophiles grew from $\mathrm{pH} 5.0$ to 8.5 , with an optimum near $\mathrm{pH} 7.0$.

These categories were therefore employed in the study of the effect of $\mathrm{pH}$ on chitin hydrolysis by enzymes in agar cylinders free of streptomycete growth (Table 2). Although the ranges of activity overlapped, the patterns of the three groups were readily distinguished and generally reflected their $\mathrm{pH}$ requirements for growth. However, the ranges for chitinolysis were broader than those for growth. Optimum hydrolysis by acidophiles was usually at $\mathrm{pH} 4.0$, while that of neutrophiles varied between $\mathrm{pH} 5.0$ and 8.0. Acidoduric isolates produced the largest zones between $\mathrm{pH} 4 \cdot 0$ and 6.0 .

\section{Properties of the $F_{2}-H$ and $A_{1}$ horizons}

Relevant properties of the horizons selected for study of chitin decomposition are given in Table 3. The organic nature of the $F_{2}-H$ horizon contrasted with the mainly mineral $A_{1}$ and this was reflected in the large differences in their nitrogen and humic acid contents. Both horizons were acidic but their buffering capacities were markedly different. The reaction of the $\mathrm{F}_{2}-\mathrm{H}$ was similar to that of citrate buffer, which increased from $\mathrm{pH} 3.7$ to 4.1 after addition 
Table 2. Effect of $p H$ on chitin hydrolysis by chitinases in agar cylinders free of streptomycete growth

Results are expressed as the mean diameter of hydrolysis zones (mm); standard errors are shown in parentheses.

\begin{tabular}{|c|c|c|c|c|c|c|c|c|}
\hline \multirow{2}{*}{$\begin{array}{l}\text { Source of } \\
\text { enzymes }\end{array}$} & \multicolumn{8}{|c|}{$\mathrm{pH}$ of medium } \\
\hline & 3.0 & 4.0 & $5 \cdot 0$ & 6.0 & $7 \cdot 0$ & $8 \cdot 0$ & 9.0 & $10 \cdot 0$ \\
\hline \multicolumn{9}{|l|}{ Acidophiles } \\
\hline SW9 & $\begin{array}{l}20.0 \\
(1.0)\end{array}$ & $\begin{array}{l}50.0 \\
(1.5)\end{array}$ & $\begin{array}{l}50.0 \\
(0)\end{array}$ & $\begin{array}{l}50 \cdot 0 \\
(0)\end{array}$ & 0 & 0 & 0 & 0 \\
\hline SW26 & $\begin{array}{l}95.7 \\
(9.8)\end{array}$ & $\begin{array}{c}133 \cdot 3 \\
(11 \cdot 8)\end{array}$ & $\begin{array}{c}107.7 \\
(12.7)\end{array}$ & $\begin{array}{l}84 \cdot 3 \\
(5 \cdot 3)\end{array}$ & 0 & 0 & 0 & 0 \\
\hline MR2 & $\begin{array}{r}125 \cdot 0 \\
(4 \cdot 9)\end{array}$ & $\begin{array}{r}154.4 \\
(7 \cdot 0)\end{array}$ & $\begin{array}{c}133.2 \\
(6.5)\end{array}$ & $\begin{array}{c}80.0 \\
(10.2)\end{array}$ & 0 & 0 & 0 & 0 \\
\hline HF3 & $\begin{array}{l}99.0 \\
(6.4)\end{array}$ & $\begin{array}{l}98.6 \\
(3.6)\end{array}$ & $\begin{array}{c}61.2 \\
(2.8)\end{array}$ & $\begin{array}{l}57.0 \\
(4.4)\end{array}$ & 0 & 0 & 0 & 0 \\
\hline \multicolumn{9}{|l|}{ Acidodurics } \\
\hline SW72 & 0 & $\begin{array}{r}212.0 \\
(9.9)\end{array}$ & $\begin{array}{l}213.0 \\
(15 \cdot 2)\end{array}$ & $\begin{array}{r}220.5 \\
(6.5)\end{array}$ & $\begin{array}{c}100.0 \\
(8.2)\end{array}$ & $\begin{array}{l}50 \cdot 0 \\
(0)\end{array}$ & $\begin{array}{l}41.2 \\
(2 \cdot 2)\end{array}$ & 0 \\
\hline $\mathrm{H}$ & 0 & $\begin{array}{r}147.0 \\
(7.0)\end{array}$ & $\begin{array}{c}213.6 \\
(19.8)\end{array}$ & $\begin{array}{r}187.8 \\
(9.8)\end{array}$ & $\begin{array}{l}86 \cdot 0 \\
(8 \cdot 3)\end{array}$ & $\begin{array}{c}41 \cdot 2 \\
(2 \cdot 2)\end{array}$ & $\begin{array}{l}41 \cdot 2 \\
(2 \cdot 2)\end{array}$ & 0 \\
\hline \multicolumn{9}{|l|}{ Neutrophiles } \\
\hline $\mathrm{Cl}$ & 0 & 0 & $\begin{array}{l}50 \cdot 0 \\
(0)\end{array}$ & $\begin{array}{c}69.0 \\
(5 \cdot 0)\end{array}$ & $\begin{array}{l}58.4 \\
(3.4)\end{array}$ & $\begin{array}{l}52.8 \\
(2.8)\end{array}$ & $\begin{array}{l}50 \cdot 0 \\
(0)\end{array}$ & $\begin{array}{l}50 \cdot 0 \\
(0)\end{array}$ \\
\hline $\mathrm{C} 5$ & 0 & 0 & $\begin{array}{l}82 \cdot 2 \\
(3 \cdot 2)\end{array}$ & $\begin{array}{r}100 \cdot 0 \\
(8 \cdot 2)\end{array}$ & $\begin{array}{l}85.4 \\
(3.9)\end{array}$ & $\begin{array}{l}82.4 \\
(5 \cdot 8)\end{array}$ & $\begin{array}{c}79 \cdot 5 \\
(15 \cdot 5)\end{array}$ & $\begin{array}{l}55 \cdot 6 \\
(3 \cdot 4)\end{array}$ \\
\hline F70 & 0 & 0 & $\begin{array}{l}178 \cdot 3 \\
(17 \cdot 2)\end{array}$ & $\begin{array}{c}185 \cdot 7 \\
(7 \cdot 7)\end{array}$ & $\begin{array}{c}202 \cdot 2 \\
(11 \cdot 0)\end{array}$ & $\begin{array}{l}222.8 \\
(12.4)\end{array}$ & $\begin{array}{l}160.0 \\
(11.0)\end{array}$ & $\begin{array}{l}137.6 \\
(10.0)\end{array}$ \\
\hline M1 & 0 & $\begin{array}{l}57.0 \\
(4.0)\end{array}$ & $\begin{array}{l}95.5 \\
(6.9)\end{array}$ & $\begin{array}{l}95.5 \\
(6.0)\end{array}$ & $\begin{array}{l}83 \cdot 0 \\
(4 \cdot 0)\end{array}$ & $\begin{array}{l}57.0 \\
(4.0)\end{array}$ & $\begin{array}{l}47.3 \\
(2.8)\end{array}$ & 0 \\
\hline
\end{tabular}

Table 3. Some properties of the $F_{2}-H$ and $A_{1}$ horizons of the Freshfield pine forest soil

\begin{tabular}{|c|c|c|c|c|c|c|}
\hline & $\mathrm{pH}$ & $\begin{array}{l}\mathrm{pH} \text { after } \\
\text { addition } \\
\text { of } 0.04 \mathrm{M}- \\
\mathrm{KOH}\end{array}$ & $\begin{array}{c}\text { Humic } \\
\text { acid } \\
(\%, w / w)\end{array}$ & $\begin{array}{c}\text { Hexosamine } \\
(\%, w / w)\end{array}$ & $\begin{array}{c}\text { Total } \\
\text { nitrogen } \\
(\%, w / w)\end{array}$ & $\begin{array}{l}\text { Organic } \\
\text { matter* } \\
(\%, w / w)\end{array}$ \\
\hline $\begin{array}{l}F_{2}-H \text { horizon } \\
A_{1} \text { horizon }\end{array}$ & $\begin{array}{l}3 \cdot 8 \\
4 \cdot 4\end{array}$ & $\begin{array}{l}4 \cdot 8 \\
9 \cdot 2\end{array}$ & $\begin{array}{r}30.4 \\
0.6\end{array}$ & $\begin{array}{l}0.39 \\
0.04\end{array}$ & $\begin{array}{c}1.2-0.95 \\
0.02\end{array}$ & $\begin{array}{l}100 \\
4.9\end{array}$ \\
\hline
\end{tabular}

of $0.04 \mathrm{M}-\mathrm{KOH}$. The $\mathrm{A}_{1}$ had little more buffering capacity than acid-washed sand, which increased from pH 5.3 to 11.8 . The high buffering capacity of the $\mathrm{F}_{2}-\mathrm{H}$ horizon was due to its high humus content. The higher hexosamine content of the $\mathrm{F}_{2}-\mathrm{H}$ was probably primarily a reflection of a larger biomass of fungi, other microbes and arthropods in this horizon.

\section{Chitin decomposition in soil}

Decomposition of chitin by actinomycetes, bacteria and fungi results in ammonification with consequent effects on soil $\mathrm{pH}$. In the $\mathrm{A}_{1}$ horizon the $\mathrm{pH}$ increased steadily from 3.8 to 7.5 over $20 \mathrm{~d}$, while the increase in the $\mathrm{F}_{2}-\mathrm{H}$ was only about $1 \mathrm{pH}$ unit (Fig. 1). Nevertheless, the rate of chitin decomposition, as indicated by release of ammonium- $\mathrm{N}$, was greater in the 


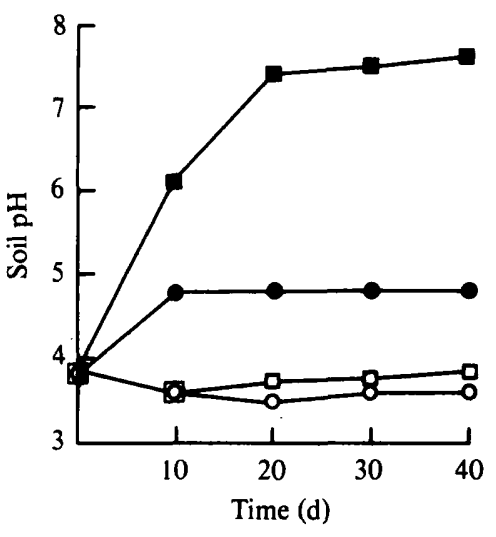

Fig. 1

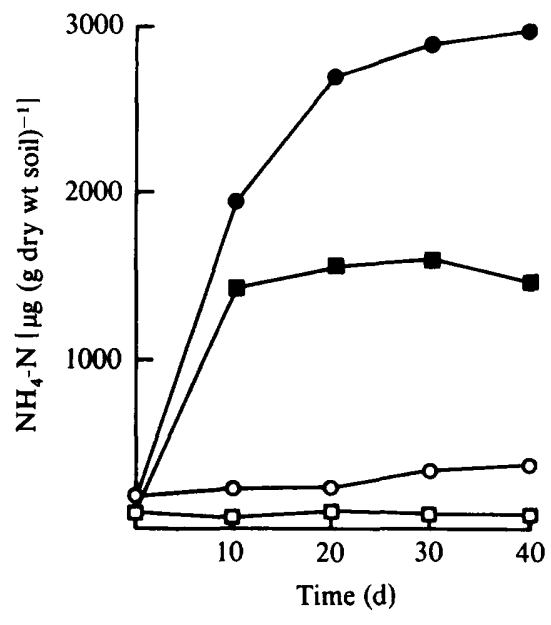

Fig. 2

Fig. 1. Changes in $\mathrm{pH}$ in the $\mathrm{F}_{2}-\mathrm{H}$ horizon control $(O)$, the $\mathrm{F}_{2}-\mathrm{H}$ plus $2.5 \%(\mathrm{w} / \mathrm{w})$ chitin $(O)$, the $A_{1}$ horizon control ( $\square$ ), and the $A_{1}$ plus $2.5 \%$ chitin ( $\square$ ).

Fig. 2. Release of ammonium-N from the $\mathrm{F}_{2}-\mathrm{H}$ horizon control $(\mathrm{O})$, the $\mathrm{F}_{2}-\mathrm{H}$ plus $2.5 \%$ (w/w) chitin (O), the $A_{1}$ horizon control ( $\square$ ), and the $A_{1}$ plus $2.5 \%$ chitin ( $\square$ ).

Table 4. Effects of chitin and fungus mycelium $(2 \cdot 5 \%, w / w)$ amendment on the $p H$ and streptomycete populations of the $F_{2}-H$ and $A_{1}$ horizons after incubation for $40 \mathrm{~d}$

Final soil pH

Changes in counts of chitinolytic streptomycetes $\ddagger$

Changes in counts of acidophilic streptomycetesł

Changes in counts of neutrophilic streptomycetes $\ddagger$

\begin{tabular}{|c|c|c|c|c|c|}
\hline \multicolumn{3}{|c|}{$\mathrm{F}_{2}-\mathrm{H}$ horizon } & \multicolumn{3}{|c|}{$\mathbf{A}_{1}$ horizon } \\
\hline Control & $\begin{array}{l}\text { Plus } \\
\text { chitin }\end{array}$ & $\begin{array}{c}\text { Plus } \\
\text { fungus } \\
\text { mycelium }\end{array}$ & Control & $\begin{array}{l}\text { Plus } \\
\text { chitin }\end{array}$ & $\begin{array}{c}\text { Plus } \\
\text { fungus } \\
\text { mycelium }\end{array}$ \\
\hline $3 \cdot 6^{*}$ & $4.8 \dagger$ & $4 \cdot 3 \dagger$ & $3 \cdot 8^{*}$ & $7.6 t$ & $5.6+$ \\
\hline 0 & $+2.7 \dagger$ & $+2 \cdot 2 \dagger$ & +0.3 & $+3 \cdot 1+$ & $+1.4 \dagger$ \\
\hline+0.8 & $+1.9 \dagger$ & $+1.9 \dagger$ & $+1 \cdot 0$ & $-5 \cdot 2 \dagger$ & $+1 \cdot 3$ \\
\hline+0.2 & $+1.6 \dagger$ & +0.5 & +0.4 & $+4.8 \dagger$ & +0.6 \\
\hline
\end{tabular}

* No significant change in $\mathrm{pH}$ during incubation period.

+ Figures significantly different from control $(P=0.05)$.

$\ddagger$ Counts expressed as $\log _{10}$ [no. (g dry wt soil) $)^{-1}$.

$F_{2}-\mathrm{H}$; final concentrations were twice those in the $A_{1}$ (Fig. 2). This was obviously a reflection of the greater buffering capacity of the $\mathrm{F}_{2}-\mathrm{H}$ horizon.

The streptomycete populations of both horizons were clearly involved in chitin decomposition, amendment leading to significant increases in counts in all cases (Table 4). Numbers of chitinolytic streptomycetes increased more or less in parallel with the total population; the proportion of chitinolytic isolates in unamended soil was high (usually $>70 \%$ ) and did not increase in amended systems.

Responses of acidophilic, acidoduric and neutrophilic streptomycetes during chitin decomposition reflected changes in soil $\mathrm{pH}$. Differences noted were largely between acidophiles and neutrophiles, as very few acidoduric strains were detected in these soils. In the $\mathrm{F}_{2}-\mathrm{H}$ horizon where the bulk $\mathrm{pH}$ reached 4.8 , both acidophiles and neutrophiles increased (Table 4); the latter were probably able to grow in micro-sites of higher pH (Williams \& 


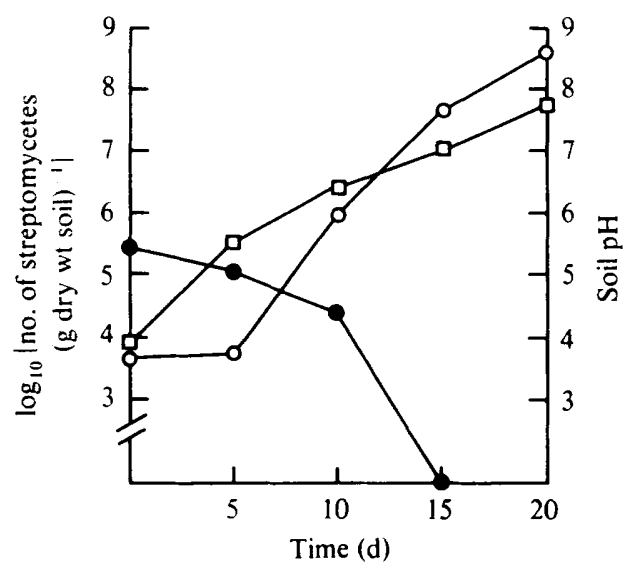

Fig. 3. Changes in numbers of neutrophilic (O) and acidophilic (O) streptomycetes, and in soil pH ( $\square$ ), in the $A_{1}$ horizon plus $2.5 \%(w / w)$ chitin.

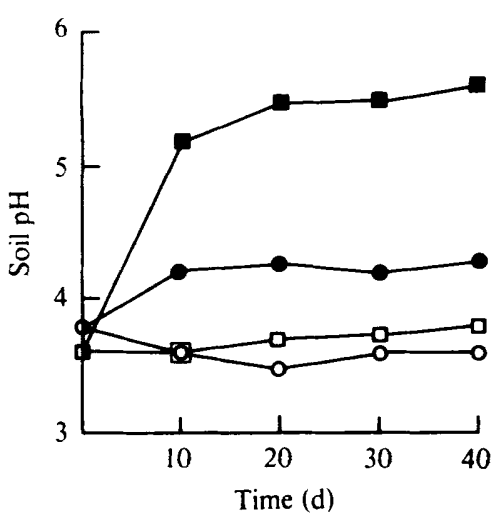

Fig. 4

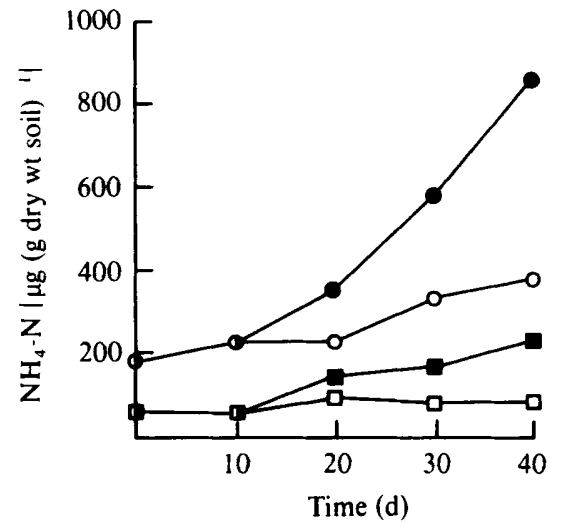

Fig. 5

Fig. 4. Changes in $\mathrm{pH}$ in the $\mathrm{F}_{2}-\mathrm{H}$ horizon control (O), the $\mathrm{F}_{2}-\mathrm{H}$ plus $2 \cdot 5 \%(\mathrm{w} / \mathrm{w})$ fungus mycelium (O), the $A_{1}$ horizon control ( $\square$ ), and the $A_{1}$ plus $2.5 \%$ fungus mycelium ( $\square$ ).

Fig. 5. Release of ammonium-N from the $F_{2}-H$ horizon control $(O)$, the $F_{2}-H$ plus $2.5 \%(w / w)$ fungus mycelium (O), the $A_{1}$ horizon control $(\square)$, and the $A_{1}$ plus $2.5 \%$ fungus mycelium ( $\square$ ).

Mayfield, 1971). Microscopic examination of amended $\mathrm{F}_{2}-\mathrm{H}$ treated with various $\mathrm{pH}$ indicators suggested spatial variation from $\mathrm{pH} 4.4$ to 6.0. The reaction of the $\mathrm{A}_{1}$ horizon reached $\mathrm{pH} 7.6$ and this resulted in a sharp increase in neutrophiles along with a decrease of acidophiles. Changes in the $A_{1}$ horizon were studied in more detail (Fig. 3). The pH rose above 5.5 after $5 \mathrm{~d}$, initiating the increase of neutrophiles and the decline of acidophiles; the latter were undetectable at $15 \mathrm{~d}$.

\section{Fungal mycelium decomposition in soil}

Amendment of both horizons with fungus mycelium also resulted in $\mathrm{pH}$ changes; the increases were smaller than those with chitin, the $A_{1}$ reaching $\mathrm{pH} 5.6$ and the $\mathrm{F}_{2}-\mathrm{H}, \mathrm{pH} 4.3$ (Fig. 4). Release of ammonium- $\mathrm{N}$ was similarly reduced, with more ammonification again occurring in the $\mathrm{F}_{2}-\mathrm{H}$ horizon (Fig. 5). There was, indeed, little evidence of decomposition in the $\mathrm{A}_{1}$ horizon. 
Numbers of chitinolytic streptomycetes were significantly increased by amendment with fungus mycelium in both horizons (Table 4), as were total numbers. In the $\mathrm{F}_{2}-\mathrm{H}$ horizon the small increase in $\mathrm{pH}$ was reflected by a stimulation of acidophiles but little increase in neutrophiles. Neither group showed significant increases in the $A_{1}$, where there was little evidence of decomposition. In contrast to the response seen after chitin amendment of the $A_{1}$ horizon, acid-tolerant streptomycetes and other soil microbes were unable to initiate decomposition to an extent sufficient to induce neutrophile activity.

\section{DISCUSSION}

Streptomycetes isolated from a wide range of soils were able to hydrolyse colloidal chitin. The $\mathrm{pH}$ optima for this process were broadly related to those for growth and to the $\mathrm{pH}$ of the soil from which isolates came. Distinctions between the activity ranges and optima of acidophiles and neutrophiles were similar to those found for starch hydrolysis by Williams \& Flowers (1978). Studies on purified chitinases from streptomycetes have indicated optimum activity at pH 7.5 (Reynolds, 1954), pH 4.2-5.0 (Skujins et al., 1970) and pH 4.2 (Skujins et al., 1974), but the growth requirements of the producing strains were not given.

Stimulation of streptomycetes by chitin amendment of soils with a reaction near to neutrality is well known and may persist for long periods. Vruggink (1970) detected 30-fold increases 10 months after addition of $1.5 \%(w / w)$ chitin. Streptomycetes clearly also play a role in chitin decomposition in acidic soil and litter, where fungi have been regarded as the most important colonizers of chitin (Gray et al., 1968). Acidophilic and acidoduric streptomycetes are also involved. Release of ammonia by the deacetylation and deamination of $\mathrm{N}$-acetylglucosamine residues may ultimately raise the pH sufficiently for activity of neutrophiles also. The behaviour of streptomycete populations in the poorly buffered $A_{1}$ horizon provided a good example of a microbial succession caused by environmental rather than nutritional changes during decomposition. Such gross increases in $\mathrm{pH}$ will rarely occur naturally in acid soil, but in localized sites of decomposition there may be an opportunity for limited growth of neutrophiles. This may account for their routine occurrence in acid soils in low numbers (Williams \& Mayfield, 1971). Ammonification in chitin-amended soils may also be of underestimated significance in the control of plant pathogenic fungi. Hora \& Baker (1972) claimed that ammonia was an important fungistatic factor in chitin-amended soil.

Addition of fungus mycelium to the two horizons induced similar but less marked changes. Ammonification, and therefore probably decomposition, was significantly less than with chitin. The major components of the walls of basidiomycetes and many other fungi are microfibrillar chitin and amorphous glucans (Bartnicki-Garcia, 1968). Figures available for other basidiomycete sporocarps indicate that those of Lactarius rufus would contain around $30-40 \%(w / w)$ chitin. This is one factor contributing to the smaller degree of ammonification. Another is that initiation of decomposition requires both glucanases and chitinases, although it has been claimed that streptomycetes often produce both (Skujins et al., 1965).

Fungal hyphae are probably the major source of chitin for streptomycetes in soil. This may not be restricted to dead hyphae, as there is evidence that streptomycetes can lyse live mycelium (Lloyd et al., 1965; Lloyd \& Lockwood, 1966). Glucosamine is the predominant hexosamine in soil hydrolysates, and this is particularly so in podzols under coniferous litter (Sowden, 1959). As fungi predominate in such acidic soils, it is likely that most of the glucosamine is derived from chitin in their walls. The hexosamine content of the $\mathrm{F}_{2}-\mathrm{H}$ horizon in the present study was similar to that of other soils examined (Stevenson, 1957; Sowden, 1959), while that of the $A_{1}$ was lower.

Therefore, streptomycetes are likely to play a major role in the decomposition of fungal material in acid litters and soils. Such materal constitutes an important substrate for microbes in these environments. The productivity of fungi within litter and soil is difficult to estimate, but sporocarps in one pine forest studied produced $30 \mathrm{~kg}$ dry wt ha $\mathrm{ha}^{-1}$ annually (Richardson, 1970). 
A research studentship (C.S.R.) from the Natural Environment Research Council is gratefully acknowledged.

\section{RE F E R E N C E S}

Bartnicki-Garcia, S. (1968). Cell wall chemistry, morphogenesis and taxonomy of fungi. Annual Review of Microbiology 22, 87-108.

Berger, L. R. \& ReYNolds, D. M. (1958). The chitinase system of a strain of Streptomyces griseus. Biochimica et biophysica acta 29, 522-534.

Flowers, T. H. \& Williams, S. T. (1977). The influence of $\mathrm{pH}$ on the growth rate and viability of neutrophilic and acidophilic streptomycetes. Microbios 18, 223-228.

Goodfellow, M., Hill, I. R. \& Gray, T. R. G. (1968). Bacteria in a pine forest soil. In The Ecology of Soil Bacteria, pp. 500-515. Edited by T. R. G. Gray \& D. Parkinson. Liverpool: Liverpool University Press.

Gray, T. R. G. \& BAXby, P. (1968). Chitin decomposition in soil. II. The ecology of chitinoclastic micro-organisms from soil. Transactions of the British Mycological Society 51, 293-309.

Gray, T. R. G., BaxbY, P., Hill, I. R. \& GoodfEllow, M. (1968). Direct observation of bacteria in soil. In The Ecology of Soil Bacteria, pp. 171-197. Edited by T. R. G. Gray \& D. Parkinson. Liverpool: Liverpool University Press.

Hora, T. S. \& BAKER, R. (1972). Soil fungistasis: microflora producing a volatile inhibitor. Transactions of the British Mycological Society 59, $491-500$.

Hsu, S. C. \& Lockwood, J. L. (1975). Powdered chitin as a selective medium for enumeration of actinomycetes in water and soil. Applied Microbiology 29, 422-426.

JENSEN, H. L. (1928). Actinomyces acidophilus n. sp. a group of acidophilous actinomycetes isolated from the soil. Soil Science 25, 225-236.

Jeuniaux, C. (1955). Production of exochitinase by Streptomyces. Comptes rendus des séances de la Société de biologie 149, 1307-1308.

Kempers, A. J. (1974). Determination of sub-micro quantities of ammonium and nitrates in soils with phenol, sodium nitroprusside and hypochlorite. Geoderma 12, 201-206.

KhaN, M. R. \& Williams, S. T. (1975). Studies on the ecology of actinomycetes in soil. VIII. Distribution and characteristics of acidophilic actinomycetes. Soil Biology and Biochemistry 7, 345-348.

Küster, E. \& Williams, S. T. (1964). Selection of media for isolation of streptomycetes. Nature, London 202, 928-929.

LINGAPPA, Y. \& Lockwood, J. L. (1962). Chitin media for selective isolation and culture of actinomycetes. Phytopathology 52, 317-323.

Lloyd, A. B. \& Lockwood, J. L. (1966). Lysis of fungal hyphae in soil and its possible relation to autolysis. Phytopathology 56, 595-602.

Lloyd, A. B., Noveroske, R. L. \& Lockwood, J. L. (1965). Lysis of fungal mycelium by Streptomyces species and their chitinase systems. Phytopathology 55, 871-875.
Mrtchell, R. (1963). Addition of fungal cell-wall components to soil for biological disease control. Phytopathology 53, 1068-1071.

Mitchell, R. \& Alexander, M. (1962). Microbiological processes associated with the use of chitin for biological control. Proceedings, Soil Science Society of America 26, 556-558.

OKAFOR, N. (1966). The ecology of micro-organisms and the decomposition of insect wings in the soil. Plant and Soil 25, 211-237.

REYNOLDS, D. M. (1954). Exocellular chitinase from a Streptomyces sp. Journal of General Microbiology 11, 150-159.

Richardson, M. J. (1970). Studies on Russula emetica and other Agarics in a Scots Pine plantation. Transactions of the British Mycological Society 55, 217-229.

Russell, E. W. (1973). Soil conditions and plant growth. London \& New York: Longman.

Skujins, J. J., Potgeiter, H. J. \& Alexander, M. (1965). Dissolution of fungal cell walls by a streptomycete chitinase and $\beta-(1-3)$ glucanase. Archives of Biochemistry and Biophysics 111, 358-364.

Skujins, J., Pukite, A. \& Mclaren, A. D. (1970). Chitinase of Streptomyces sp.: purification and properties. Enzymologia 39, 353-370.

Skujins, J., Pukite, A. \& Mclaren, A. D. (1974). Adsorption and activity of chitinase on kaolinite. Soil Biology and Biochemistry 6, 179-182.

Sneh, B., Katan, J. \& Henis, Y. (1971). Mode of inhibition of Rhizoctonia solani in chitin amended soil. Phytopathology 61, 1113-1117.

SOWDEN, F. J. (1959). Investigations on the amounts of hexosamines found in various soils and methods for their determination. Soil Science 88, 138-143.

STEVENSON, F. J. (1957). Investigations of aminopolysaccharides in soils. I. Colorimetric determination of hexosamines in soil hydrolysates. Soil Science 83, 113-122.

SteVEnSON, F. J. (1965). Amino sugars. In Methods of Soil Analysis, pp. 1429-1436. Edited by C. A. Black. Madison, Wisconsin: American Society of Agronomy.

Tiunova, N. A., Pirieva, D. A., Feniksova, R. V. \& KUZNETSOV, V. D. (1976a). Formation of chitinase by actinomycetes in submerged culturing. Mikrobiologiya 45, 246-248 (English translation).

Tiunova, N. A., Pirieva, D. A. \& Feniksova, R. V. $(1976 b)$. Formation and properties of chitinase of Actinomyces kurssanovii. Microbiologiya 45, 543-546 (English translation).

VRUGGink, H. (1970). The effect of chitin amendment on actinomycetes in soil and on the infection of potato tubers by Streptomyces scabies. Netherlands Journal of Plant Pathology 76, 293-295.

Weatherburn, M. W. (1967). Phenol-hypochlorite reaction for determination of ammonia. Analytical Chemistry 39, 971-974. 
Wellington, E. M. H. \& Williams, S. T. (1978). Preservation of actinomycete inoculum in frozen glycerol. Microbios Letters 6, 151-157.

Williams, S. T. \& MAYFIELD, C. I. (1971). Studies on the ecology of actinomycetes in soil. III. The behaviour of neutrophilic streptomycetes in acid soil. Soil Biology and Biochemistry 3, 197-208.

Williams, S. T. \& Flowers, T. H. (1978). The influence of $\mathrm{pH}$ on starch hydrolysis by neutrophilic and acidophilic streptomycetes. Microbios 20, 99106.

Williams, S. T., Davies, F. L., Mayfield, C. I. \& Khan, M. R. (1971). Studies on the ecology of actinomycetes in soil. II. The $\mathrm{pH}$ requirements of streptomycetes from two acid soils. Soil Biology and Biochemistry 3, 187-195. 